ANL-7264

ANL-7264

241

Argonne Mational Laboratow

MACRODETERMINATION OF OXYGEN IN URANIUM DIOXIDE COMPOSITES BY

INERT-GAS FUSION

by

Harvey T. Goodspeed and Dewitt Pettis 


\section{DISCLAIMER}

This report was prepared as an account of work sponsored by an agency of the United States Government. Neither the United States Government nor any agency Thereof, nor any of their employees, makes any warranty, express or implied, or assumes any legal liability or responsibility for the accuracy, completeness, or usefulness of any information, apparatus, product, or process disclosed, or represents that its use would not infringe privately owned rights. Reference herein to any specific commercial product, process, or service by trade name, trademark, manufacturer, or otherwise does not necessarily constitute or imply its endorsement, recommendation, or favoring by the United States Government or any agency thereof. The views and opinions of authors expressed herein do not necessarily state or reflect those of the United States Government or any agency thereof. 


\section{DISCLAIMER}

Portions of this document may be illegible in electronic image products. Images are produced from the best available original document. 
The facilities of Argonne National Laboratory are owned by the United States Government. Under the terms of a contract (W-31-109-Eng-38) between the U. S. Atomic Energy Commission, Argonne Universities Association and The University of Chicago, the University employs the staff and operates the Laboratory in accordance with policies and programs formulated, approved and reviewed by the Association.

\section{MEMBERS OF ARGONNE UNIVERSITIES ASSOCIATION}

The University of Arizona Carnegie Institute of Technology

Case Institute of Technology

Tho Univer eity of rhiragn

University of Cincinnati

Illinois Institute of Technology

University of Illinois

Indiana University

Iowa State University
The University of Iowa Kansas State University The University of Kansas Inyola University Marquette University Michigan State University The University of Michigan University of Minnesota University of Missouri
Northwestern University University of Notre Dame The Ohio State University Purdue University Saint Louis University Washington University Wayne State University The University of Wisconsin

\section{LEGAL NOTICE}

This report was prepared as an account of Government sponsored work. Neither the United States, nor the Commission, nor any person acting on behalf of the Commission:

A. Makes any warranty or representation, expressed or implied, with respect to the accuracy, completeness, or usefulness of the information contained in this report, or that the use of any information, apparatus, method, or process disclosed in this report may not infringe privately owned rights; or

B. Assumes any liabilities with respect to the use of, or for damages resulting from the use of any information, apparatus, method, or process disclosed in this report.

As used in the above, "person acting on behalf of the Commission" includes any employee or contractor of the Commission, or employee of such contractor, to the extent that such employee or contractor of the Commission, or employee of such contractor prepares, disseminates, or provides access to, any information pursuant to his employment or contract with the Commission, or his employment with such contractor.

Printed in the United States of America Available from

Clearinghouse for Federal Scientific and Technical Information National Bureau of Standards, U.S. Department of Commerce Springfield, Virginia 22151

Price: Printed Copy $\$ 3.00$; Microfiche $\$ 0.65$ 


\title{
MACRODETERMINATION OF OXYGEN IN \\ URANIUM DIOXIDE COMPOSITES BY INERT-GAS FUSION
}

\section{by}

Harvey T. Goodspeed and Dewitt Pettis

\author{
Chemistry Division
}

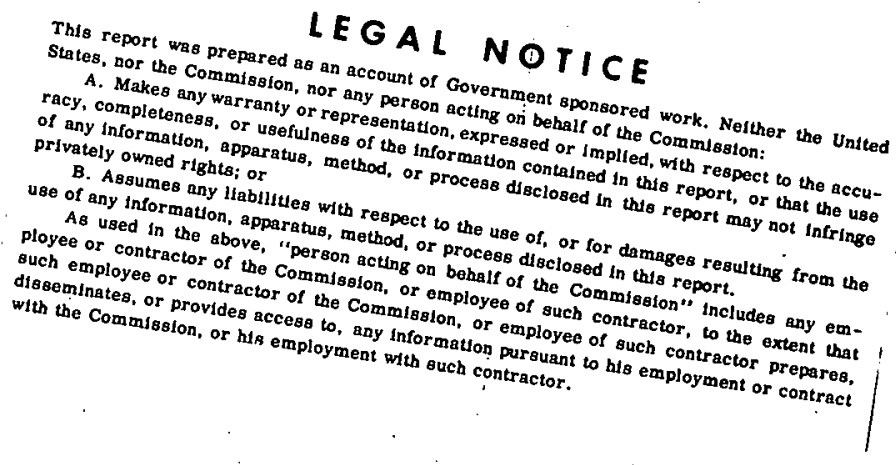

September 1967 
TABLE OF CONTENTS

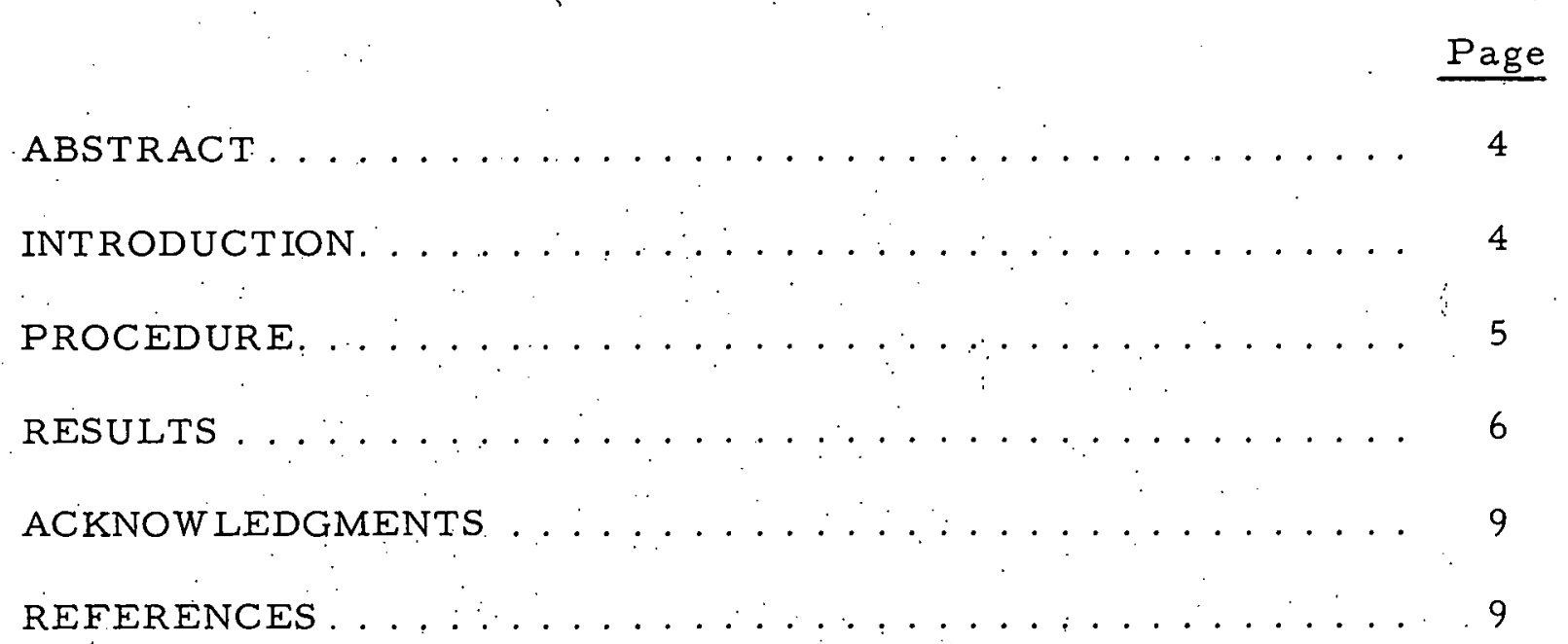




\section{LIST OF FIGURES}

No.

Title

Page

1. Cross Section of Carbon Crucible and Lid. .......... 5

2. Schematic Diagram of Manometric and Gravimetric Trains . . . 6

\section{LIST OF TABLES}

No.

Title

$\underline{\text { Page }}$

I. Recovery Data on $\mathrm{U}_{3} \mathrm{O}_{8} \ldots \ldots \ldots \ldots \ldots$

II. Percentage of Oxygen in $\mathrm{UO}_{2} \ldots \ldots \ldots \ldots \ldots$

III. Recovery Data Obtained on Tungsten- $\mathrm{UO}_{2}$ Composites . . . . 8

IV. Analysis of Thorium Oxide-Uranium Oxide Composites . . . 8

V. Analysis of $\mathrm{ZrO}_{2}-\mathrm{UO}_{2}$ Composites ............. 8

VI. Analysis of Rare-earth Oxides- $\mathrm{UO}_{2}$ Composites . . . . . . . 9

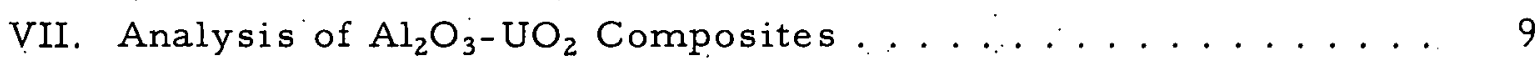




\title{
MACRODETERMINATION OF OXYGEN IN URANIUM DIOXIDE COMPOSITES BY INERT-GAS FUSION
}

by

Harvey T. Goodspeed and Dewitt.Pettis

\begin{abstract}
This report describes an inert-gas fusion method for the macrodetermination of oxygen in uranium dioxide composites. Sample sizes ranged around $300 \mathrm{mg}$. About $100 \mathrm{mg}$ of $\mathrm{CO}_{2}$ produced by the procedure was collected in absorptionweighing tubes and measured on a standard analytical balance. As an initial check on the method, it has been applied with success to oxygen determinations for various standard materials other than $\mathrm{UO}_{2}$ composites. When applied to uranium dioxide composites, the method gives results that again appear to be completely satisfactory when temperature is taken to be the critical factor and therefore controlled.

Average recoveries of 99.9 and $100.1 \%$ of the theoretical oxygen content were obtained in the analysis of $\mathrm{U}_{3} \mathrm{O}_{8}$ and $\mathrm{UO}_{2}$ standards, with standard deviations from the means of about $0.3 \%$. The same degree of precision.was obtained in the oxygen analysis of known samples of $\mathrm{W}-\mathrm{UO}_{2}$ composites. Results obtained in the oxygen analyses of composites of $\mathrm{UO}_{2}$ and other metal oxides are presented in tabular form.
\end{abstract}

\section{INTRODUCTION}

Two methods in current use for the direct determination of oxygen in oxides are the bromine trifluoride method, with its various modifications, ${ }^{1-3}$ and the inert-gas fusion method. ${ }^{4}$

In every version of the procedure used for the determination of oxygen in metal oxides by inert-gas fusion, the temperature was initially held for a time at a given precalibrated setting ${ }^{4}$ and then raised in two steps.

By a later approach to the procedure, the initial temperature and the time the crucible was kept at this temperature were governed by the ratio of the uranium dioxide to the composite material. 
This report describes the procedure used and the results obtained in the determination of oxygen in composites of $\mathrm{UO}_{2}$ and other metal oxides.

\section{PROCEDURE}

The procedure described here is basically the same as that in Ref. 4, the major change being in temperature control. In this report, the
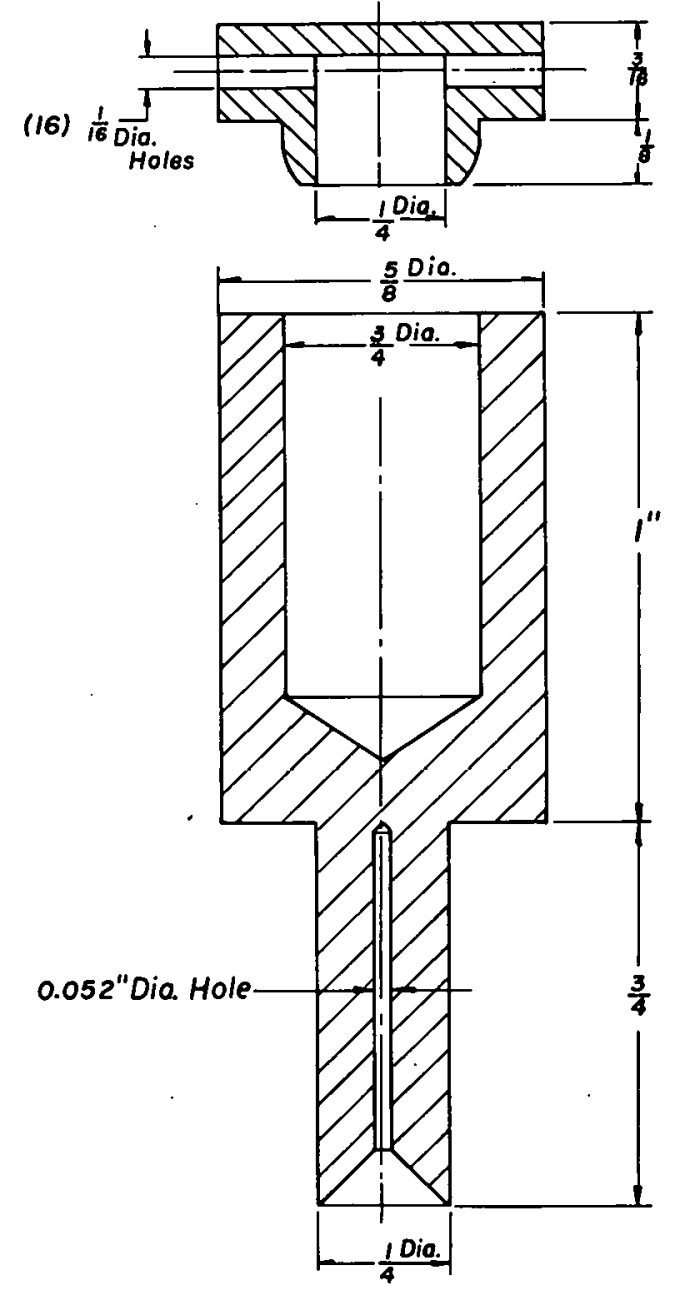

$120-7099$

Fig. 1. Cross Section of Carbon Crucible and Lid power to the induction heating coil was set so that the temperature of the crucible lid (shown in the upper part of Fig. 1) was raised to a point which, by a previous calibration, corresponds to a temperature of about $1650^{\circ} \mathrm{C}$ inside the crucible. The procedure is as follows:

1. Manipulate the stopcocks to direct a flow of argon gas of about $150 \mathrm{cc} /$ min through the reaction tube, the $\mathrm{CuO}$ furnace, the desiccating tube, the weighing tube, and the manometric train, ${ }^{5}$ which is operated in series with the gravimetric train as a precaution against incomplete removal of $\mathrm{CO}_{2}$ in the weighing tube. Throttle the gas flow at the inlet stopcock of the capillary manometer. Figure 2 shows the relationship of the components involved in this step.

2. Apply power to the induction heater to raise the temperature of the crucible lid, watching closely for the appearance of smoke from the crucible. Then immediately decrease the input power until the smoking diminishes almost to extinction.

3. Maintain this power and temperature level for $15 \mathrm{~min}$. The initial temperature inside the crucible (1550 to $1650^{\circ} \mathrm{C}$ ) will vary with each oxide sample depending upon the ratio of $\mathrm{UO}_{2}$ to the composite material.

4. Increase the input power to raise the temperature of the lid about $150^{\circ} \mathrm{C}$, and maintain this level for $10 \mathrm{~min}$. 
5. Finally, boost the power to produce a temperature of about $2000^{\circ} \mathrm{C}$ inside the crucible, and hold this level for $5 \mathrm{~min}$.

6. Disconnect and weigh the weighing tube, using the technique described in Ref. 4.

7. From the total amount of $\mathrm{CO}_{2}$ measured, deduct the prevailing blank (usually about $0.3 \mathrm{mg}$ ) obtained by proceeding through steps $1-6$ above, using an empty platinum capsule for the sample.

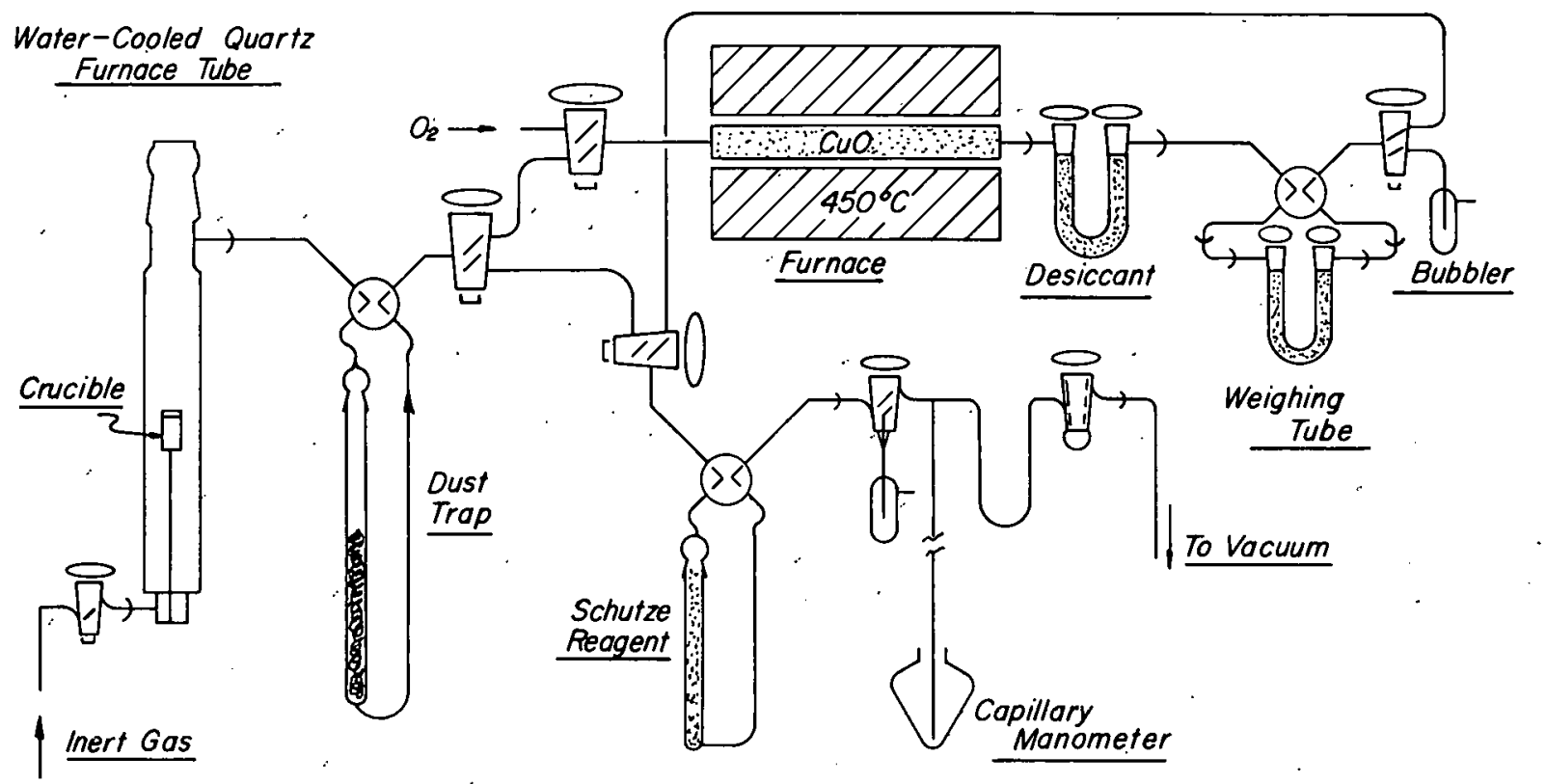

120-7100 Rev. 1

Fig. 2. Schematic Diagram of Manometric and Gravimetric Trains

\section{RESULTS}

During the investigation, more and more effort was devoted toward operation at the minimum temperature effective in the reduction of a given oxide within a 15-min period. As might be expected, this minimum varied from one oxide to another, being slightly lower for tungsten- $\mathrm{UO}_{2}$ than for $\mathrm{U}_{3} \mathrm{O}_{8}$. The oxide samples that produced more than $150 \mathrm{mg}$ of $\mathrm{CO}_{2}$ frequently smoked when the temperature was increased after the 15-min initial temperature period. These phenomena were usually accompained by low results. When smoke appears during the reduction reaction, it may be assumed that $\mathrm{CO}$ is being released too rapidly and that some of the oxide dust particles are being carried away by entrainment. ${ }^{4}$ With these precautions in mind, some $\mathrm{UO}_{2}$ composites were analyzed. Tables I-VII illustrate the precision obtained for oxygen analysis by following this procedure. 
TABLE I. Recovery Data on $\mathrm{U}_{3} \mathrm{O}_{8}$ (NBS Sample 950a)

\begin{tabular}{cccc}
\hline $\begin{array}{c}\text { Oxygen } \\
\begin{array}{c}\text { Content, } \\
\%\end{array}\end{array}$ & Recovery, \% & $\begin{array}{c}\text { Oxygen } \\
\text { Content, } \\
\%\end{array}$ & Recovery, \% \\
\hline 15.20 & 100.0 & 15.18 & 99.9 \\
15.21 & 100.1 & 15.19 & 99.9 \\
15.28 & 100.5 & 15.25 & 100.3 \\
15.16 & 99.7 & 15.18 & 99.9 \\
15.23 & 100.2 & Av. 100.1 & \\
& & Std. Dev. \pm 0.3 & \\
\hline
\end{tabular}

TABLE II. Percentage of Oxygen in $\mathrm{UO}_{2}$

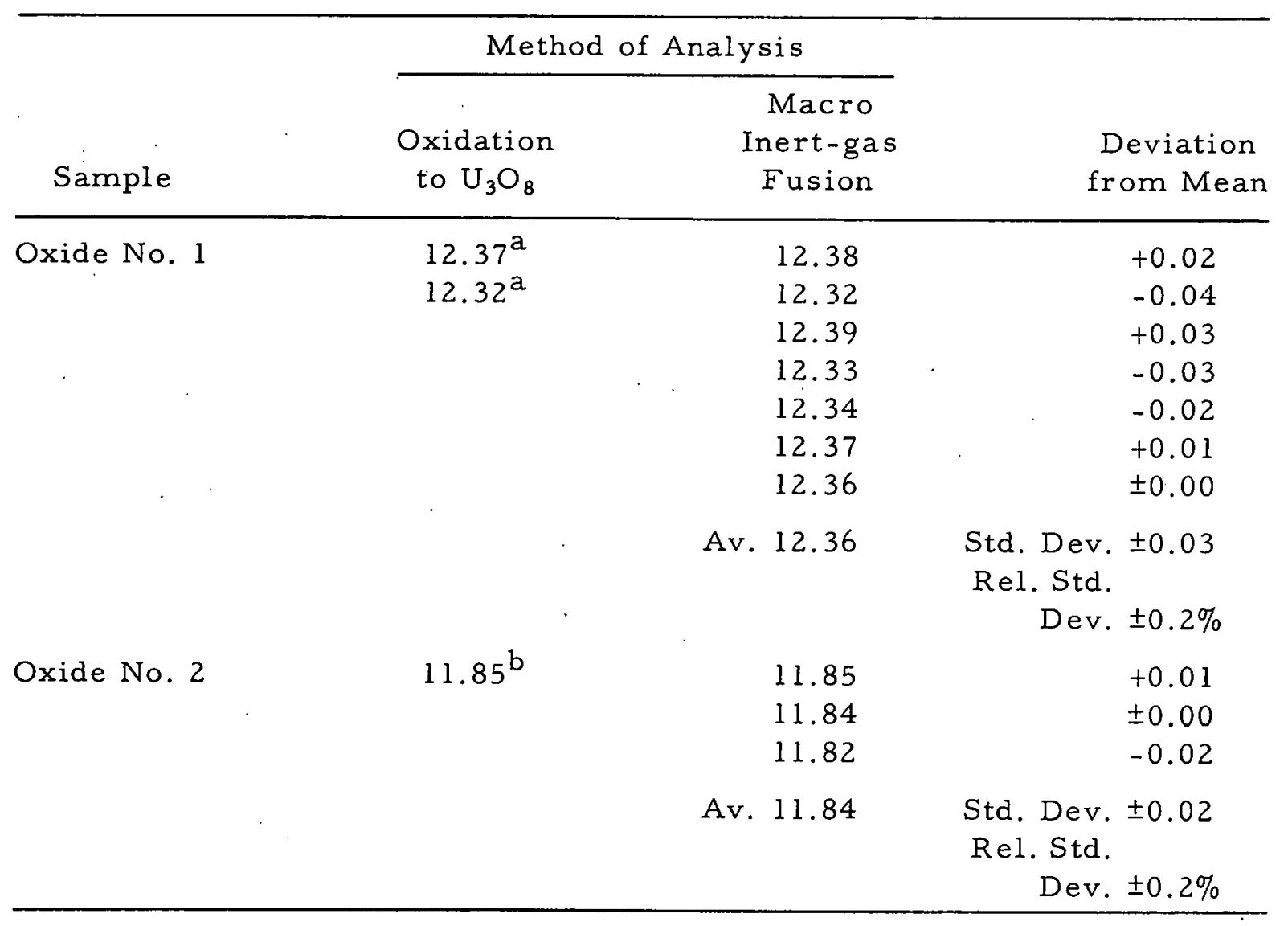

${ }_{\text {B }}$ y ANL Chemical Engineering Division.

${ }^{b}$ By ANL Chemistry Division. 
TABLE III. Recovery Data Obtained on Tungsten- $\mathrm{UO}_{2}$ Composites .

\begin{tabular}{|c|c|c|c|}
\hline \multirow[b]{2}{*}{$\begin{array}{c}\text { Sample } \\
\left(\mathrm{W}^{\mathrm{a}}+\mathrm{UO}_{2} \mathrm{~b}\right)\end{array}$} & \multicolumn{2}{|c|}{ Oxygen Content, $\%$} & \multirow[b]{2}{*}{ Recovery, $\%$} \\
\hline & Calculated & $\begin{array}{c}\text { Macro } \\
\text { Inert-gas } \\
\text { Fusion }\end{array}$ & \\
\hline No. 1 & 8.70 & 8.67 & 99.7 \\
\hline No. 2 & 10.21 & 10.22 & 100.1 \\
\hline No. 3 & 9.39 & 9.38 & 99.9 \\
\hline No. 4 & 9.10 & 9.11 & 100.1 \\
\hline No. 5 & 10.89 & $10: 88$ & 99.9 \\
\hline No. 6 & 9.62 & 9.60 & 99.8 \\
\hline & & & $\begin{array}{rr}\text { Av. } & 99.9 \\
\text { Std. Dev. } & \pm 0.2\end{array}$ \\
\hline
\end{tabular}

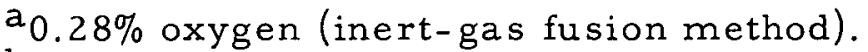

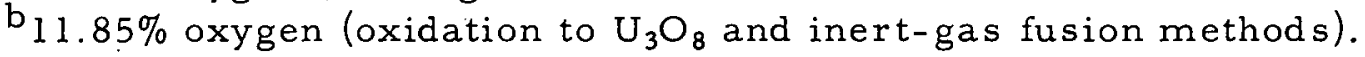

TABLE IV. Analysis of

Thorium Oxide-Uranium

Oxide Composites

\begin{tabular}{|c|c|c|}
\hline Sample & $\begin{array}{c}\text { Oxygen, } \\
\%\end{array}$ & $\begin{array}{c}\text { Difference } \\
\text { between } \\
\text { Duplicates, } \\
\%\end{array}$ \\
\hline No.1 & $\begin{array}{l}11.81 \\
11.80\end{array}$ & 0.01 \\
\hline No. 2 & $\begin{array}{l}11.91 \\
11.80\end{array}$ & 0.11 \\
\hline No. 3 & $\begin{array}{l}11.91 \\
11.88\end{array}$ & 0.03 \\
\hline No. 4 & $\begin{array}{l}11.69 \\
11.70\end{array}$ & 0.01 \\
\hline No. 5 & $\begin{array}{l}11.83 \\
11.78\end{array}$ & 0.05 \\
\hline \multicolumn{3}{|c|}{$\begin{array}{r}\text { Av. Diff. } 0.04 \\
\text { Rel. Std. Diff. } 0.5 \%\end{array}$} \\
\hline
\end{tabular}

TABLE V. Analysis of $\mathrm{ZrO}_{2}-\mathrm{UO}_{2}$ Composites

\begin{tabular}{|c|c|c|}
\hline Sample & $\underset{\%}{\text { Oxygen, }}$ & $\begin{array}{c}\text { Difference } \\
\text { between } \\
\text { Duplicates } \\
\%\end{array}$ \\
\hline $\left.\begin{array}{l}\mathrm{ZrO}_{2}(5 \mathrm{~m} / \mathrm{o})+ \\
\mathrm{UO}_{2}(95 \mathrm{~m} / \mathrm{o})\end{array}\right\}$ & $\begin{array}{l}12.15 \\
12.19\end{array}$ & 0.04 \\
\hline $\left.\begin{array}{l}\mathrm{ZrO}_{2}(10 \mathrm{~m} / \mathrm{o}) \\
\mathrm{UO}_{2}(90 \mathrm{~m} / \mathrm{o})\end{array}\right\}$ & $\begin{array}{l}12.55 \\
12.52\end{array}$ & 0.03 \\
\hline $\left.\begin{array}{l}\mathrm{ZrO}_{2}(5 \mathrm{~m} / \mathrm{o}) \\
\mathrm{UO}_{2}(95 \mathrm{~m} / \mathrm{o})\end{array}\right\}$ & $\begin{array}{l}12.09 \\
12.12\end{array}$ & 0.03 \\
\hline $\left.\begin{array}{l}\mathrm{ZrO}_{2}(10 \mathrm{~m} / \mathrm{o}) \\
\mathrm{UO}_{2}(90 \mathrm{~m} / \mathrm{o})\end{array}\right\}$ & $\begin{array}{l}12.30 \\
12.25\end{array}$ & 0.05 \\
\hline & $\begin{array}{r}\text { Av. } \\
\text { Rel. Std. }\end{array}$ & $\begin{array}{ll}\text { Diff. } & 0.04 \\
\text { Diff. } & 0.3 \%\end{array}$ \\
\hline
\end{tabular}


TABLE VI. Analysis of Rare-earth Oxides- $\mathrm{UO}_{2}$ Composites

\begin{tabular}{|c|c|c|}
\hline Sample & $\begin{array}{c}\text { Oxygen, } \\
\%\end{array}$ & $\begin{array}{c}\text { Difference } \\
\text { between } \\
\text { Duplicates } \\
\%\end{array}$ \\
\hline $\mathrm{SmO}_{2}+\mathrm{UO}_{2}$ & $\begin{array}{l}12.30 \\
12.24\end{array}$ & 0.06 \\
\hline $\mathrm{SmO}_{2}+\mathrm{UO}_{2}$ & $\begin{array}{l}12.09 \\
12.16\end{array}$ & 0.07 \\
\hline $\mathrm{Eu}_{2} \mathrm{O}_{3}+\mathrm{UO}_{2}$ & $\begin{array}{l}12.01 \\
12.01\end{array}$ & 0.00 \\
\hline $\mathrm{Eu}_{2} \mathrm{O}_{3}+\mathrm{UO}_{2}$ & $\begin{array}{l}12.05 \\
12.05\end{array}$ & 0.00 \\
\hline $\mathrm{Gd}_{2} \mathrm{O}_{3}+\mathrm{UO}_{2}$ & $\begin{array}{l}12.09 \\
12.06\end{array}$ & 0.03 \\
\hline $\mathrm{Gd}_{2} \mathrm{O}_{3}+\mathrm{UO}_{2}$ & $\begin{array}{l}12.21 \\
12.27\end{array}$ & 0.06 \\
\hline $\mathrm{Gd}_{2} \mathrm{O}_{3}+\mathrm{UO}_{2}$ & $\begin{array}{l}11.90 \\
11.77\end{array}$ & 0.13 \\
\hline $\mathrm{Gd}_{2} \mathrm{O}_{3}+\mathrm{UO}_{2}$ & $\begin{array}{l}12.08 \\
12.06\end{array}$ & 0.02 \\
\hline $\mathrm{Gd}_{2} \mathrm{O}_{3}+\mathrm{UO}_{2}$ & $\begin{array}{l}11.86 \\
11.84\end{array}$ & 0.02 \\
\hline \multirow[t]{2}{*}{$\mathrm{Gd}_{2} \mathrm{O}_{3}+\mathrm{UO}_{2}$} & $\begin{array}{l}12.29 \\
12.30\end{array}$ & 0.01 \\
\hline & $\begin{array}{r}\text { Av. } \\
\text { Rel. Std. }\end{array}$ & $\begin{array}{ll}\text { Diff. } & 0.04 \\
\text { Diff. } & 0.5 \%\end{array}$ \\
\hline
\end{tabular}

TABLE VII. Analysis of $\mathrm{Al}_{2} \mathrm{O}_{3}-\mathrm{UO}_{2}$ Composites

\begin{tabular}{|c|c|c|}
\hline Sample & $\begin{array}{c}\text { Oxygen, } \\
\%\end{array}$ & $\begin{array}{c}\text { Difference } \\
\text { between } \\
\text { Duplicates } \\
\%\end{array}$ \\
\hline No. 1 & $\begin{array}{l}12.23 \\
12.28\end{array}$ & 0.05 \\
\hline No. 2 & $\begin{array}{l}12.34 \\
12.14\end{array}$ & 0.20 \\
\hline No. 3 & $\begin{array}{l}12.61 \\
12.43\end{array}$ & 0.18 \\
\hline No. 4 & $\begin{array}{l}11.93 \\
11 . .86\end{array}$ & 0.07 \\
\hline No. 5 & $\begin{array}{l}11.85 \\
11.83\end{array}$ & 0.02 \\
\hline No. 6 & $\begin{array}{l}12.55 \\
12.74\end{array}$ & 0.19 \\
\hline No. 7 & $\begin{array}{l}12.00 \\
12.05\end{array}$ & 0.05 \\
\hline No. 8 & $\begin{array}{l}12.44 \\
12.54\end{array}$ & 0.10 \\
\hline & \multicolumn{2}{|c|}{$\begin{aligned} & \text { Av. Diff. } 0.11 \\
& \text { Rel. Std. Diff. } 1.1 \%\end{aligned}$} \\
\hline
\end{tabular}

\section{ACKNOWLEDGMENTS}

We are grateful to Adolph Venters, John H. Marsh, Jr., and John E. Stoessel for the preparation of the tungsten- $\mathrm{UO}_{2}$ samples referred to in Table III.

\section{REFERENCES}

1. W. A. Dupraw and H. J. O'Neill, Anal. Chem. 31, 1104 (1959).

2. H. R. Hoekstra and J. J. Katz, Ibid. 25, 1609 (1953).

3. I. Sheft, A. F. Martin, and J. J. Katz, J. Am. Chem. Soc. 78, 1557 (1956).

4. B. D. Holt and J. E. Stoessel, Anal. Chem. 36, 1320 (1964).

5. W. G. Smiley, Ibid. 27, 1098 (1955). 
